\title{
Determining the Differences in Acute Phase of Astrocytic Activation Between Male and Female Rats - A Research Protocol
}

Yaqian G. Zhang, BHSc Student [1]*, Sumin Lee, BHSc Student [1], Rachel Chin, BHSc Student [1]

[1] Department of Health Sciences, Queen's University, Kingston, Ontario, Canada K7L 3N6

*Corresponding Author: grace.zhang@queensu.ca

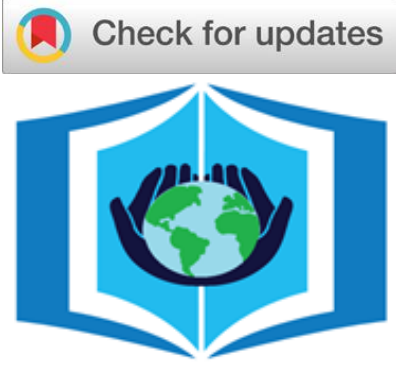

URNCST Journal

"Research in Earnest"

\begin{abstract}
Introduction: Primary blast injuries are a common cause of mild traumatic brain injury (mTBI) and are the leading cause of both closed and open-skull brain injuries. Following mTBI, astrocytic activation and reactive gliosis occur which results in an upregulation of various astrocytic markers such as glial fibrillary acidic protein (GFAP). These markers can act as biomarkers for patients with mTBI. This protocol will examine how primary blast injury affects the acute phase of astrocytic activation in male and female rats.

Rationale: This experiment will determine the sex differences in astrocytic activation after male and female rodent mTBI to replicate the effects of primary blast injury resulting from improvised explosive device (IED) impact in humans. These injuries are the most common cause of concussions in deployed military personnel. Understanding sex differences in the extent of astrocytic activation and the time window between blast impact and initial activation will have implications for trauma treatment in the field to prevent excessive neurodegeneration. There is also a lack of research on the sex-specific acute astrocytic activation resulting from blast injuries.

Methods: Adult male and female wild-type Sprague Dawley rats will be randomly assigned to (a) male sham, (b) female sham, (c) male mTBI, or (d) female mTBI group. After each rat is exposed to the primary blast injury, coronal sections of the brains will be collected. Flow cytometry and quantitative polymerase chain reaction (qPCR) will be used to analyze astrocytic gene expression.

Expected Results: For the 48-hour duration following primary blast injuries, GFAP levels are expected to increase to different extents for both males and females. We expect this difference between males and females to occur due to hormonal suppression of astrogliosis in females.

Discussion: The analysis of astrocytic activation among female and male rats caused by closed skull blast-specific injury will help to determine sex-specific treatments and therapeutic applications for injured military soldiers.

Conclusion: This study will allow for a greater understanding of sex differences in astrocytic activation, which may benefit treatment plans for mTBI patients.
\end{abstract}

Keywords: GFAP; glial fibrillary acidic protein; astrocytes; gliosis; astrogliosis; mTBI; mild traumatic brain injury; blast injury; closed-skull injury; sex differences

\section{Introduction}

Astrocytes are the most abundant cell in the mammalian human brain [1] and participate in synapse formation, plasticity, and homeostasis [2]. Mild traumatic brain injuries (mTBIs), namely concussions, involve a period of unconsciousness and loss of memory, and they can impair the brain's cellular energetic metabolism [3,4]. Following mTBI, astrocytes often undergo reactive gliosis, in which astrocytic activation initiates certain physiological responses such as inflammation [5]. During astrocytic activation and reactive gliosis, there is an increase in the production of intermediate filament proteins and changes in the gene expression (refer to Table 1) [6]. Proteins such as glial fibrillary acidic protein (GFAP) act as biomarkers for patients with mTBI [7]. For this reason, astrocytic biomarker gene expression and its associated protein concentration levels are known to increase after traumatic brain injuries [8]. These changes in the gene and morphological hallmarks of astrocytes can cause significant functional changes for stroke, trauma, epilepsy, Alzheimer's disease, and other neurodegenerative diseases [6].

One common injury associated with mTBIs is blast injuries although they have not been well investigated [9]. Blast injuries can be classified into primary, secondary, tertiary and quaternary blast injuries [9]. Primary blast injuries involve traumatic brain injury from blast waves moving throughout the body; secondary blast injuries are explosive injuries that cause ballistic trauma from the 
UNDERGRADUATE RESEARCH IN NATURAL AND CLINICAL SCIENCE AND TECHNOLOGY (URNCST) JOURNAL Read more URNCST Journal articles and submit your own today at: https://www.urncst.com

explosive device or the environment; tertiary blast injuries result from displacement from the blast wind; finally, quaternary explosive injuries are caused by burns, toxins, or radiological contamination [9]. As primary blast injuries are the leading cause of both closed and open brain injuries in military personnel [9], this protocol will use a rat model to explore the impact of primary blast injury on acute phases of astrocytic activation.

\section{Rationale}

Rodent models are most commonly used to study astrocytic activation in response to mTBI in humans. Rodent models and in-vitro experiments have linked neurodegenerative diseases with the inflammatory responses resulting from acute astrocytic activation following mTBI [5]. Understanding the extent of astrocytic activation and the time window between blast impact and initial activation will have implications for military trauma treatment in preventing excessive neurodegeneration. Focusing our investigation on the sex differences in astrocytic activation among rodents and the use of improvised explosive devices (IEDs) are justified below.

Sex differences were considered because the current literature only looks at astrocytic activation in male rodents due to confounding variables experienced by female rodents, such as their monthly hormonal cycle. However, significant differences in activation could potentially have implications in male and female mild mTBI outcomes, such as survival and cognition which have previously been reported [10]. Therefore, to further explore these differences, female rats were incorporated into this study. Since 'ideal' biomarkers may differ between males and females [11,12], they could be used to improve therapeutic interventions, therefore optimizing patient recovery and increasing treatment success rates.

Blast injuries from IEDs are the most common cause of concussion among military service members deployed to Iraq and Afghanistan [13]. Explosive blasts and missile attacks can result in a traumatic brain injurt (TBI) even if the head does not collide with an object $[13,14]$. This may prove valuable to field medics and rescue teams sent to retrieve soldiers from missile and explosive blast attacks. Furthermore, the acute phase of injury could be an important time for therapeutic intervention. Uncontrolled neuroinflammation plays a major role in the pathogenesis of various disease processes, which could potentially also drive progressive neurodegeneration [5].

\section{Methods \\ Animals}

Adult male and female wild-type Sprague Dawley rats will be randomly assigned to one of four groups: a) male sham, b) female sham, c) male mTBI, and d) female mTBI. Within each intervention group, rats will be further divided into 6 subdivisions to indicate the time of euthanasia postblast injury. Rats will be kept under normal living and feeding conditions prior to the injury. Rats will be housed in standard laboratory cages on a 12-hour light/dark cycle and at a controlled temperature of $22 \pm 1^{\circ} \mathrm{C}$ [15]. Rats will undergo a 7-day period of handling acclimatization prior to the blast exposure [16]. This is done to ensure the safety of the research team and to protect the welfare of the animals.

\section{Tissue Processing}

On the day of the blast injury, rats will be put under general anesthesia using isoflurane gas $[17,18]$, and a single, primary-grade blast injury will be administered using a blast nozzle [19]. Sham groups will also receive anesthesia and be placed in the blast compartment, but they will not receive the blast exposure. At 0 hr, 1 hr, 6 hrs, 12 hrs, 24 hrs, and $48 \mathrm{hrs}$ post-blast injury, carbon dioxide $\left(\mathrm{CO}_{2}\right)$ inhalation will be used to euthanize the rats [18] and coronal sections of brains will be collected immediately afterwards (Figure 1).

\section{Tissue Collection \& Analysis}

To quantify this activation, flow cytometry and quantitative polymerase chain reaction (qPCR) will be used to measure the expression of astrocytic biomarkers. Astrocytes will be collected at time points listed above by flow cytometry. Brain cell cultures will be centrifuged, separated from the supernatant, and resuspended in a buffer solution before being injected into the flow cytometer for astrocyte identification [20]. Once astrocytic cell cultures are identified and isolated, they will be centrifuged, and the resulting cell pellets will be collected for qPCR. A genomic deoxyribonucleic acid (DNA) kit will be then used to extract astrocytic DNA, and qPCRs will be performed using a SYBR Green polymerase chain reaction (PCR) master mix kit [21]. Primers will be designed to amplify the genes outlined in Table 1. Emitted fluorescence for each sequence will be measured and graphed as a standard curve, with emitted fluorescence on the $\mathrm{y}$-axis, the number of qPCR cycles on the $\mathrm{x}$-axis, and the $\mathrm{C}_{\mathrm{T}}$ threshold fluorescence value as the horizontal crossing point for each linear regression [21].

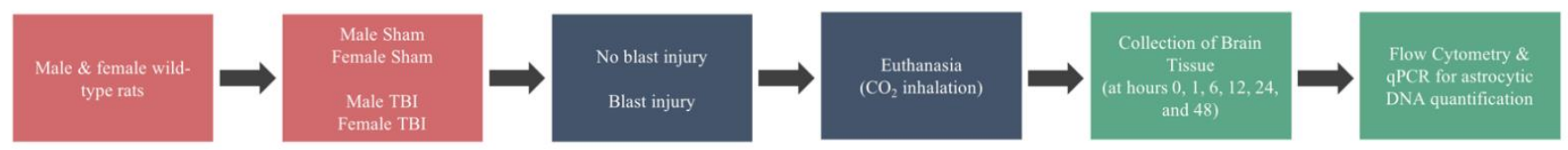

Figure 1. A flowchart summarizing the study methodology. Red sections indicate the process of group randomization, blue sections highlight the methods used for tissue processing, and green sections indicate techniques used for tissue collection and analysis. This figure was created using Microsoft PowerPoint. 
UNDERGRADUATE RESEARCH IN NATURAL AND CLINICAL SCIENCE AND TECHNOLOGY (URNCST) JOURNAL

Read more URNCST Journal articles and submit your own today at: https://www.urncst.com

Table 1. Potential markers of reactive astrocytes [22]

\begin{tabular}{|c|c|}
\hline Marker & Function \\
\hline \multicolumn{2}{|l|}{ Cytoskeleton } \\
\hline GFAP & Intermediate filament \\
\hline Nestin & Intermediate filament \\
\hline Synemin & Intermediate filament \\
\hline Vimentin & Intermediate filament \\
\hline \multicolumn{2}{|l|}{ Metabolism } \\
\hline ALDOC & Glycolytic enzyme \\
\hline BLBP/ FABP7 & Lipid transport \\
\hline MAO-B & Catecholamine \\
\hline TSPO & Mitochondrial lipid transporter \\
\hline \multicolumn{2}{|l|}{ Chaperones } \\
\hline CRYAB & Chaperone activity \\
\hline HSPB1/HSP27 & Chaperone \\
\hline \multicolumn{2}{|l|}{ Secreted Proteins } \\
\hline $\mathrm{C} 3$ & Complement factor \\
\hline CHI3L1/ YKL40 & Unclear function \\
\hline $\operatorname{Lcn} 2$ & Iron trafficking protein \\
\hline Serpina3n/ACT & Serine protease inhibitor \\
\hline MT & Metal Binding \\
\hline THBS-1 & Synaptogenic factor \\
\hline \multicolumn{2}{|c|}{ Cell Signalling (Transcription Factors) } \\
\hline NFAT & Transcription factor \\
\hline $\begin{array}{l}\text { NTRK2/ TrkB } \\
\text { IL17R }\end{array}$ & Receptors \\
\hline S100B & $\begin{array}{l}\mathrm{Ca}^{2+} \text { binding protein for cell } \\
\text { signalling }\end{array}$ \\
\hline SOX9 & Transcription factor \\
\hline STAT3 & Transcription factor \\
\hline \multicolumn{2}{|c|}{ Channel Transporters } \\
\hline EAAT1 \& 2 & Glutamate transporters \\
\hline KIR4.1 & $\mathrm{K}^{+}$channel \\
\hline
\end{tabular}

\section{Results}

Between 0 and 48 hours following the blast injuries, the expression of astrocytic biomarkers in both male and female sham groups are expected to remain constant throughout this time period while the expression of all astrocytic biomarkers in both male and female TBI groups are expected to increase [2]. However, the expression level of each biomarker is expected to differ between genders. The current literature shows that males often have a higher level of expression compared to females [23].

While male humans often recover faster from mTBI [24], animal models have consistently demonstrated better recovery and fewer post-mTBI complications among female test subjects [25]. As mentioned previously, astrogliosis following mTBI triggers certain physiological responses such as neural tissue inflammation.

\section{Discussion}

The current literature does not specify whether astrocytic responses to blast injury diseases are sexspecific, as most papers only study the effects of blast injuries on astrocytes in male animals $[17,18]$. Nevertheless, quantifying astrocyte-mediated inflammatory responses between sex will have valuable implications in trauma treatment for head injuries. While this difference has not been investigated, the current literature supports the hypothesis that males and females will respond differently to acute brain damage due to their differences in hormonal secretion. Studies have shown that gonadal hormones have neuroprotective properties to counter inflammatory responses [24]. Estrogen and progesterone specifically have been linked to reduced water retention and edema in the brain following mTBI [24]. Since females often have higher levels of estrogen and progesterone, the hormonal suppression of astrogliosis in females will likely affect astrocytic biomarker expression levels. Ultimately, it may produce different mTBI outcomes compared to males.

In addition, most of the current literature only looks at the long-term effects of astrogliosis following mTBI or the effect of astrogliosis in neurodegenerative diseases such as Alzheimer's. Very few studies focus on acute astrocytic activation and its immediate impact on the body and brain. As this paper specifically focuses on blast-injuries, this mimics the injuries most commonly experienced by deployed military personnel [13]. Understanding the effects of acute inflammation from blast-induced mTBI would be beneficial for field medics in treating and triaging injured soldiers. The literature suggests that uncontrolled neuroinflammation contributes significantly to pathogenesis and progressive neurodegeneration [5]. Thus, investigating the extent of astrogliosis and subsequent inflammation in the acute injury phase will dictate the time period for optimal therapeutic intervention.

As the research study focused on female and male rats, it is somewhat difficult to generalize the results to humans. In addition to the fact that rats do not replicate humans entirely, the laboratory settings do not mimic the heterogeneity of the real world. Furthermore, the study primarily focuses on closed-skull and blast-specific injuries. As such, there may be differences in the effects of astrocytic activation as a result of an open-skull injury or other types of impacts. This could limit the experiment 
UNDERGRADUATE RESEARCH IN NATURAL AND CLINICAL SCIENCE AND TECHNOLOGY (URNCST) JOURNAL Read more URNCST Journal articles and submit your own today at: https://www.urncst.com

from exploring the implications of a variety of injuries. The act of euthanizing the rodent before collecting brain tissue samples could be another limitation as it could potentially alter the gene expression that occurred during the process. Therefore, this study could possibly diversify the type of test organisms and injury types to improve its overall generalizability to humans.

\section{Conclusion}

The purpose of this experimental proposal is to examine the differences in the initial phases of astrocytic activation between male and female rats. Once undergoing a primary-grade blast injury, rats would be euthanized at 0 hr, $1 \mathrm{hr}, 6 \mathrm{hrs}, 12 \mathrm{hrs}, 24 \mathrm{hrs}$, and $48 \mathrm{hrs}$ post-blast injury so that coronal sections of the brain can be collected. Flow cytometry and qPCR would then be used to measure expression levels of various biomarkers for astrocytic activation.

The current literature suggests that astrocytic activation could be a precursor to progressive neurodegeneration [5], and research has shown that hormonal differences between sexes have implications for differences in survival and cognitive function following brain injury. Based on this information, current treatments could be optimized to account for sex differences in astrocytic activation. Experiments that compare therapeutic interventions between males and females should also be conducted in the future to further support the importance of sex differences in astrogliosis and its implications in controlling acute inflammation and treating mTBIs.

\section{List of Abbreviations Used}

GFAP: glial fibrillary acidic protein

IED: improvised explosive device

TBI: traumatic brain injury

mTBI: mild traumatic brain injury

PCR: polymerase chain reaction

qPCR: quantitative polymerase chain reaction

$\mathrm{CO}_{2}$ : carbon dioxide

DNA: deoxyribonucleic acid

\section{Conflicts of Interest}

The authors declare that they have no conflict of interests.

\section{Ethics Approval and/or Participant Consent}

No ethics approval or participant consent was required as this is only a proposed research protocol.

\section{Authors' Contributions}

YGZ: contributed to study design and planning, assisted with the collection and analysis of data, and gave final approval of the version to be published.

SL: contributed to study design and planning, assisted with the collection and analysis of data, and gave final approval of the version to be published.

$\mathrm{RC}$ : contributed to study design and planning, assisted with the collection and analysis of data, and gave final approval of the version to be published.

\section{Acknowledgement}

We want to acknowledge Prashanth Velayudhan for his guidance and support in writing this paper.

\section{Funding}

This study was not funded.

\section{References}

[1] Freeman MR. Specification and morphogenesis of astrocytes. Science. 2010 Nov 5;330(6005):774-8. https://doi.org/10.1126/science.1190928

[2] Burda JE, Bernstein AM, Sofroniew MV. Astrocyte roles in traumatic brain injury. Experimental Neurology 2016 Jan;275(3):305-15. https://doi.org/ 10.1016/j.expneurol.2015.03.020

[3] Arciniegas DB, Anderson CA, Topkoff J, McAllister TW. Mild traumatic brain injury: A neuropsychiatric approach to diagnosis, evaluation, and treatment. Neuropsychiatric Disease and Treatment. 2005 Dec;1(4):311-27. Available from: https://www.ncbi .nlm.nih.gov/pmc/articles/PMC2424119/

[4] Vagnozzi R, Signoretti S, Cristofori L, Alessandrini F, et al. Assessment of metabolic brain damage and recovery following mild traumatic brain injury: A multicentre, proton magnetic resonance spectroscopic study in concussed patients. Brain. 2010 Nov;133(11): 3232-42. https://doi.org/10.1093/brain/awq200

[5] Karve IP, Taylor JM, Crack PJ. The contribution of astrocytes and microglia to traumatic brain injury. British Journal of Pharmacology 2016 Feb;173(4):692702. https://doi.org/10.1111/bph.13125

[6] Pekny M, Wilhelmsson U, Pekna M. The dual role of astrocyte activation and reactive gliosis. Neuroscience Letters. 2014 Apr 17;565:30-8. https://doi-org.proxy .queensu.ca/10.1016/j.neulet.2013.12.071

[7] Gill J, Latour L, Diaz-Arrastia R, Motamedi V, Turtzo C, Shahim P, et al. Glial fibrillary acidic protein elevations relate to neuroimaging abnormalities after mild TBI. Neurology. 2018 Oct 9;91(15):e1385-9. https://doi.org/10.1212/WNL.0000000000006321 
UNDERGRADUATE RESEARCH IN NATURAL AND CLINICAL SCIENCE AND TECHNOLOGY (URNCST) JOURNAL Read more URNCST Journal articles and submit your own today at: https://www.urncst.com

[8] Huebschmann NA, Luoto TM, Karr JE, Berghem K, Blennow K, Zetterberg H, et al. Comparing glial fibrillary acidic protein (GFAP) in serum and plasma following mild traumatic brain injury in older adults. Frontiers in Neurology. 2020;11. https://doi.org/ 10.3389/fneur.2020.01054

[9] Ritenour AE, Baskin TW. Primary blast injury: Update on diagnosis and treatment. Critical Care Medicine. 2008 Jul;36(7):S311-317. https://doi.org/10.1097/ CCM.0b013e31817e2a8c

[10] Bazarian JJ, Blyth B, Mookerjee S, He H, McDermott MP. Sex differences in outcome after mild traumatic brain injury. Journal of Neurotrauma. 2010;27(3):52739. https://doi-org.proxy.queensu.ca/10.1089/neu.2009 .1068

[11] $\overline{\mathrm{Ma} C}$, Wu X, Shen X, Yang Y, Chen Z, Sun X, et al. Sex differences in traumatic brain injury: A multidimensional exploration in genes, hormones, cells, individuals, and society. Chinese Neurosurgical Journal. 2019;5(1). https://doi.org/10.1186/s41016019-0173-8

[12] Munivenkatappa A, Agrawal A, Shukla DP, Kumaraswamy D, Devi BI. Traumatic brain injury: Does gender influence outcomes? International Journal of Critical Illness and Injury Science. 2016;6(2):70. https://doi.org/10.4103\%2F2229-5151 .183024

[13] Blast Injury [Internet]. BrainLine. 2017 [cited 2021 Mar 20]. Available from: https://www.brainline.org/ identifying-and-treating-concussionmtbi-servicemembers-and-veterans/about-concussionmtbi/blast

[14] 109 US troops diagnosed with TBI after Iran missile barrage says Pentagon in latest update [Internet]. Military Times. 2020 [cited 2021 Mar 20]. Available from: https://www.militarytimes.com/news/yourmilitary/2020/02/10/more-than-100-us-troopsdiagnosed-with-tbi-after-irans-attack-at-al-asad-report/

[15] BALB/c Mouse | Charles River Laboratories. [Internet]. [cited 2021 Mar 20]. Available from: https://www.criver.com/products-services/findmodel/balbc-mouse?region=3611

[16] Kemp R. Handling and Restraint of Rats [Internet]. Available from: http://www.usp.br/bioterio/Artigos/ Procedimentos\%20experimentais/HandlingThe_Labora tory Rat-By George J_Krinke.pdf
[17] Readnower RD, Chavko M, Adeeb S, Conroy MD, Pauly JR, McCarron RM, et al. Increase in blood-brain barrier permeability, oxidative stress, and activated microglia in a rat model of blast-induced traumatic brain injury. Journal of Neuroscience Research. 2010;88(16):3530-9. https://doi-org/10.1002/jnr.22510

[18] Gama Sosa MA, De Gasperi R, Perez Garcia GS, Perez GM, Searcy C, Vargas D, et al. Low-level blast exposure disrupts gliovascular and neurovascular connections and induces a chronic vascular pathology in rat brain. Acta Neuropathologica Communications. 2019 Jan 9;7(1):6. https://doi.org/10.1186/s40478-018$\underline{0647-5}$

[19] Risling M, Davidsson J. Experimental animal models for studies on the mechanisms of blast-induced neurotrauma. Frontiers in Neurology. 2012 Apr 2;3:30. https://doi.org/10.3389/fneur.2012.00030

[20] Irwin RJ, Lerner MR, Bealer JF, Lightfoot SA, Brackett DJ, Tuggle DW. Global primary blast injury: A rat model. Journal of the Oklahoma State Medical Association. 1998;91(7):387-392. Available from: https://pubmed.ncbi.nlm.nih.gov/9793276/

[21] Ostergaard PJ, Jensen MB. Histological quantification of astrocytosis after cerebral infarction: A systematic review. International Journal of Neuroscience. 2013 Jul;123(7):439-43. https://doi.org/10.3109/00207454 .2013 .765421

[22] Loftie-Eaton W, Tucker A, Norton A, Top EM. Flow cytometry and real-time quantitative PCR as tools for assessing plasmid persistence. Applied and Environmental Microbiology. 2014 Aug 8. https://doi.org/10.1128/AEM.00793-14

[23] Conejo NM, González-Pardo H, Pedraza C, Navarro FF, Vallejo G, Arias JL. Evidence for sexual difference in astrocytes of adult rat hippocampus. Neuroscience Letters. 2003;339(2):119-22. https://doi.org/10.1016/ S0304-3940(02)01484-2

[24] Bazarian JJ, Blyth B, Mookerjee S, He H, McDermott MP. Sex differences in outcome after mild traumatic brain injury. Journal of Neurotrauma. 2010 Mar;27(3):527-39. https://doi-org.proxy.queensu.ca/ $\underline{10.1089 / \text { neu.2009.1068 }}$

[25] MMa C, Wu X, Shen X, Yang Y, Chen Z, Sun X, et al. Sex differences in traumatic brain injury: A multidimensional exploration in genes, hormones, cells, individuals, and Society. Chinese Neurosurgical Journal. 2019;5(1). https://doi.org/10.1186/s41016$\underline{019-0173-8}$

\section{Article Information}

Managing Editor: Jeremy Y. Ng

Peer Reviewers: Prashanth Velayudhan, Bi-ru Amy Yeung

Article Dates: Received Apr 05 21; Accepted Sep 22 21; Published Oct 1421 
UNDERGRADUATE RESEARCH IN NATURAL AND CLINICAL SCIENCE AND TECHNOLOGY (URNCST) JOURNAL

Read more URNCST Journal articles and submit your own today at: https://www.urncst.com

\section{Citation}

Please cite this article as follows:

Zhang YG, Lee S, Chin R. Determining the differences in acute phase of astrocytic activation between male and female rats - A research protocol. URNCST Journal. 2021 Oct 14:5(10).

https://urncst.com/index.php/urncst/article/view/268

DOI Link: https://doi.org/10.26685/urncst.268

\section{Copyright}

(C) Yaqian G. Zhang, Sumin Lee, Rachel Chin. (2021). Published first in the Undergraduate Research in Natural and Clinical Science and Technology (URNCST) Journal. This is an open access article distributed under the terms of the Creative Commons Attribution License (https://creativecommons.org/licenses/by/4.0/), which permits unrestricted use, distribution, and reproduction in any medium, provided the original work, first published in the Undergraduate Research in Natural and Clinical Science and Technology (URNCST) Journal, is properly cited. The complete bibliographic information, a link to the original publication on http://www.urncst.com, as well as this copyright and license information must be included.

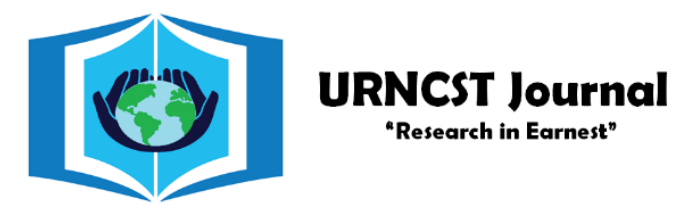

\section{Funded by the \\ Government of Canada}

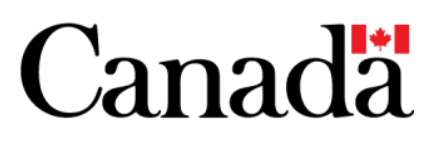

Do you research in earnest? Submit your next undergraduate research article to the URNCST Journal!

| Open Access | Peer-Reviewed | Rapid Turnaround Time | International |

| Broad and Multidisciplinary | Indexed | Innovative | Social Media Promoted |

Pre-submission inquiries? Send us an email at info@ urncst.com | Facebook, Twitter and LinkedIn: @URNCST

Submit YOUR manuscript today at https://www.urncst.com! 